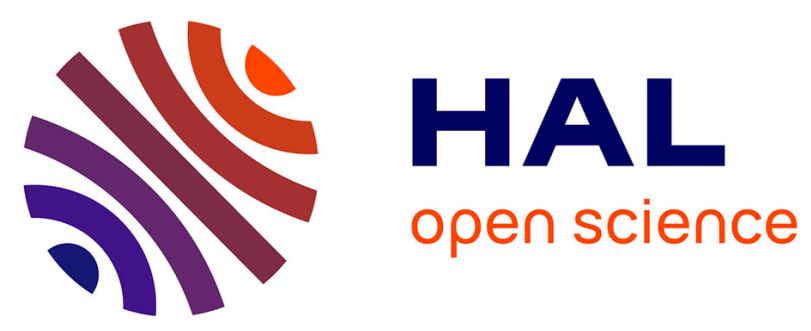

\title{
Marginal and internal fit of CAD-CAM inlay/onlay restorations: A systematic review of in vitro studies
} Alexis Goujat, Hazem Abouelleil, Pierre Colon, Christophe Jeannin, Nelly Pradelle, Dominique Seux, Brigitte Grosgogeat

\section{To cite this version:}

Alexis Goujat, Hazem Abouelleil, Pierre Colon, Christophe Jeannin, Nelly Pradelle, et al.. Marginal and internal fit of CAD-CAM inlay/onlay restorations: A systematic review of in vitro studies. The Journal of Prosthetic Dentistry, 2019, 121 (4), pp.590-597.e3. 10.1016/j.prosdent.2018.06.006 . hal02360059

\section{HAL Id: hal-02360059 \\ https://hal.science/hal-02360059}

Submitted on 22 Oct 2021

HAL is a multi-disciplinary open access archive for the deposit and dissemination of scientific research documents, whether they are published or not. The documents may come from teaching and research institutions in France or abroad, or from public or private research centers.
L'archive ouverte pluridisciplinaire HAL, est destinée au dépôt et à la diffusion de documents scientifiques de niveau recherche, publiés ou non, émanant des établissements d'enseignement et de recherche français ou étrangers, des laboratoires publics ou privés.

\section{다)(1) $(5$}

Distributed under a Creative Commons Attribution - NonCommercial| 4.0 International 
JPD-18-295

\section{SYSTEMATIC REVIEW}

Marginal and internal fit of CAD-CAM inlay/onlay restorations: A systematic review of in vitro studies

Alexis Goujat, MSD, ${ }^{a}$ Hazem Abouelleil, MSD,${ }^{b}$ Pierre Colon, $\mathrm{PhD},{ }^{\mathrm{c}}$ Christophe Jeannin, PhD, ${ }^{\mathrm{d}}$ Nelly Pradelle, $\mathrm{PhD},{ }^{\mathrm{e}}$ Dominique Seux, $\mathrm{PhD},{ }^{\mathrm{f}}$ and Brigitte Grosgogeat, $\mathrm{PhD}^{\mathrm{g}}$

${ }^{\mathrm{a} A s s o c i a t e}$ Professor, Laboratory of Multimaterials and Interfaces, UMR CNRS 5615, Lyon1 University; Faculty of Odontology, Department of Restorative Dentistry, Lyon Civil Hospices, Lyon, France.

${ }^{\mathrm{b}}$ Associate Professor, Laboratory of Multimaterials and Interfaces, UMR CNRS 5615, Lyon1 University; Faculty of Odontology, Department of Prosthodontics, Lyon Civil Hospices, Lyon, France.

${ }^{\mathrm{c}}$ Professor, Laboratory of Multimaterials and Interfaces, UMR CNRS 5615, Lyon1 University; Faculty of Odontology, Department of Restorative Dentistry, Rothschild Hospital, Paris, France.

${ }^{\mathrm{d}}$ Associate Professor, Laboratory of Multimaterials and Interfaces, UMR CNRS 5615, Lyon1 University; Faculty of Odontology, Department of Prosthodontics, Lyon Civil Hospices, Lyon, France.

${ }^{\mathrm{e}}$ Associate Professor, Laboratory of Multimaterials and Interfaces, UMR CNRS 5615, Lyon1 University, Faculty of Odontology, Department of Restorative Dentistry, Rothschild Hospital, Paris, France. 
${ }^{\mathrm{f}}$ Professor, Laboratory of Multimaterials and Interfaces, UMR CNRS 5615, Lyon1 University; Faculty of Odontology, Department of Restorative Dentistry, Lyon Civil Hospices, Lyon, France.

${ }^{\mathrm{g}}$ Professor, Laboratory of Multimaterials and Interfaces, UMR CNRS 5615, Lyon1 University; Faculty of Odontology, Department of Dental Biomaterials, Lyon Civil Hospices, Lyon, France.

\begin{abstract}
Statement of problem. Different parameters can influence the adaptation of computer-aided design and computer-aided manufacturing (CAD-CAM) inlay/onlay restorations. However, systematic reviews to identify and discuss these parameters are lacking.

Purpose. The purpose of this systematic review was to summarize the scientific literature investigating all parameters that can influence both the marginal and internal adaptation of CADCAM inlay/onlay restorations.
\end{abstract}

Material and methods. An electronic search was conducted by 2 independent reviewers for studies published in English between January 1, 2007 and September 20, 2017 on the PubMed/Medline, Scopus, and Web of Science databases and in accordance with the Preferred Reporting Items for Systematic Reviews and Meta-Analyses (PRISMA) statement. Factors investigated in the selected articles included the type of CAD-CAM system, virtual space parameters, version of the software, type of block, luting procedure, type of restoration, sample size and aging procedure, evaluation method, and number of measurement points per specimen. Results. A total of 162 articles were identified, of which 23 met the inclusion criteria. Nine studies investigated adaptation with different restorative materials, 2 evaluated adaptation according to the type of preparation design, 9 compared adaptation before/after 
thermomechanical loading (TML) and 2 before/after cementation, 1 study investigated marginal adaptation whether the optical scan was made intraorally or extraorally, 1 compared adaptation with 5 and 3 axis CAM systems, and 1 assessed adaptation with 4 different intraoral scanners. The risk of bias was high for 7 , medium for 15 , and low for 1 of the studies reviewed. The high level of heterogeneity across the studies excluded meta-analysis.

Conclusions. Most of the studies reported clinically acceptable values for marginal adaptation. The performance of a CAD-CAM system is influenced by the type of restorative material. A nonretentive cavity preparation exhibited better adaptation than a retentive preparation. Most studies showed that TML affected the quality of marginal adaptation. Cementation increased marginal discrepancies. No statistically significant difference was found for marginal fit of onlays between an intraoral and extraoral optical scans using a stone die. The number of milling axes, the type of digital camera, and the region measured were statistically significant in relation to marginal/internal adaptation. Values of adaptation recorded failed to reproduce the preestablished spacer parameters in the software. Clarification is needed concerning adaptation according to the type of preparation design, the type of material, the choice of intrinsic parameters for the CAD process, the type and shape of milling burs, and the behavior of the material during milling. Adaptation of CAD-CAM inlay/onlays should be evaluated under clinical conditions.

\section{CLINICAL IMPLICATIONS}

Practitioners should be aware that the type of cavity preparation, the choice of the restorative material, the optical scan, and the parameters related to the CAD process may influence the adaptation of inlay/onlay restorations. 


\section{INTRODUCTION}

Computer-aided design and computer-aided manufacturing (CAD-CAM) and intraoral digital scanners have become popular as alternatives to conventional impression making and casting methods, especially with the introduction of a new range of digitalization tools and scanners. ${ }^{1-3}$ The fabrication process comprises scanning the abutment tooth, designing the prosthesis, and milling the restoration in a centralized milling center or with a laboratory or chairside process. ${ }^{4}$ The potential for CAD-CAM to enhance prosthesis accuracy is based on the omission of several fabrication steps, and CAD-CAM may offer similar or better results than conventional methods. ${ }^{5}$ Inlay/onlay restorations represent a more conservative approach than complete coverage crowns and can be made with less retention form because of advances in the quality of luting procedures. ${ }^{6}$ In addition, polymerization shrinkage for indirect composite resin restorations is limited to the cement space. ${ }^{7}$ The performance of CAD-CAM inlay/onlays is satisfactory with a success rate of $88.7 \%$ for ceramics over a period of 10 years $^{8}$ and $84.78 \%$ for composite resins over a period of 5 years. ${ }^{9}$

Current materials used for inlay/onlay restorations are glass ceramic blocks and composite resin blocks. Glass ceramics include feldspathic porcelain (Mark II; Vita Zahnfabrik), leucite-reinforced ceramics (Empress CAD; Ivoclar Vivadent, Initial LRF Block; GC Dental Products), lithium disilicate (e.max CAD; Ivoclar Vivadent), and zirconia-lithium monosilicatereinforced glass ceramic blocks (Suprinity; Vita Zahnfabrik, Celtra Duo; Sirona Dentsply). ${ }^{10}$ CAD-CAM technology has enabled the use of new composite resin blocks with dispersed fillers (Lava Ultimate; 3M ESPE, Cerasmart; GC Dental Products) and a polymer infiltrated ceramic network (PICN) material (Enamic; Vita Zahnfabrik). ${ }^{10-13}$ These new materials are polymerized 
under high pressure and high temperature (HP/HT). Therefore, this process yields higher mechanical and biological properties than conventionally polymerized composite resins. ${ }^{12,13}$ Moreover, these new composite resin blocks have improved resistance to fracture and machinability due to a low elastic modulus close to dentin. ${ }^{12,14-16}$

Several factors affect the longevity of an indirect restoration, including the quality of the marginal and internal adaptation. Poor marginal adaptation can lead to microleakage, dissolution of the luting cement, secondary caries, and gingival inflammation. ${ }^{17-27}$ In addition, poor internal fit can increase cement thickness, alter retention, affect occlusion, reduce the fracture resistance of the restorations, and also result in poor marginal fit. ${ }^{9,27,28}$ Marginal and internal adaptation is of particular importance for inlay/onlay restorations, as their margins are exposed to mechanical, physical, and thermal stresses.

The authors are unaware of a systematic review describing marginal and internal adaptation of CAD-CAM inlay/onlay restorations. Thus, the purpose of this study was to review in vitro studies and especially those in relation to CAD-CAM technology which can influence both marginal and internal adaptation of these restorations.

\section{MATERIAL AND METHODS}

The protocol for this systematic review (CRD42017076069) was registered in the international prospective register of systematic reviews (https://www.crd.york.ac.uk/PROSPERO/). This systematic review was performed according to the Preferred Reporting Items for Systematic Reviews and Meta-Analyses (PRISMA) statement. ${ }^{29}$ An electronic search was performed, using 3 electronic databases (PubMed/MEDLINE, Scopus, and Web of Science) for studies published between January 1, 2007 and September 20, 2017. A search strategy was prepared for each 
database using 4 levels: level 1 considering the adaptation quality, level 2 considering the type of material, level 3 considering CAD-CAM technology, and level 4 considering the type of restoration. The search strategy included the following medical subject headings $(\mathrm{MeSH})$ : 'Ceramic', 'Inlay*', and the following text words: 'fit', 'gap', 'marginal', 'internal', 'adaptation', 'discrepancy', 'resin', 'composite', 'CAD', 'computer-aided', and 'onlay'. The PubMed/MEDLINE search is presented in Table 1. Inclusion criteria included articles published in English concerning in vitro studies, only inlay and/or onlay (partial-coverage crown) restorations, and evaluating marginal and/or internal fit in micrometers or in percentage of continuous margin (\%gap-free) on natural or artificial teeth. Interim CAD-CAM blocks, implant abutments, reviews, abstracts, short communications, books, and animal studies were excluded. Initially, 2 independent reviewers (A.G.,D.S.) reviewed titles and abstracts. After considering the inclusion and exclusion criteria, full texts were selected for both reading and final selection. All differences in choices between the 2 authors were analyzed by a third reviewer (H.A.), and agreement was established through discussion. The factors extracted from the selected studies and subsequently analyzed were, in order, authors and years, CAD-CAM systems, virtual space parameters, versions of the software, types of block, types of restoration, sample size and aging procedures, numbers of measurement points per specimen, marginal and/or internal fit recorded, luting procedures, and evaluation methods. Because of the high degree of heterogeneity in terms of different studies and methodologies, a meta-analysis was not appropriate.

Two authors (A.G., D.S.) independently evaluated the risk of bias of each included study using an adaptation of the methods applied in 2 previous systematic reviews of in vitro studies. ${ }^{30,31}$ Descriptions of the following parameters were used to assess each article's risk of bias (Supplemental Table 1): randomization of the teeth for experimental groups, blinding of the 
operator, number of measurement points per specimen (>50, according to Groten et $\mathrm{al}^{32}$ ), presence of a control group, statistical analysis carried out, gap measurement by a single operator, and luting space parameter specified. A 'Yes' was assigned where the parameter was reported in the text and a 'No' if the information was absent. The risk of bias was classified according to the sum of 'Yes' received as follows: 1 to $3=$ high, 4 to $5=$ medium, 6 to $7=$ low risk of bias.

\section{RESULTS}

The electronic search identified 162 articles, 31 from PUBMED/Medline, 53 from Scopus, and 78 from Web of Science. After duplicated articles had been removed and the inclusion and exclusion criteria considered, 23 articles remained. ${ }^{6,7,17,19-21,24,25,28,33-46}$ Details of the search strategy are presented in a flow diagram (Fig. 1). The parameters recorded for all included studies are described in Supplemental Tables 2, 3 and Figure 2.

Values for the marginal fit of the studies selected ranged between $36 \mu \mathrm{m}^{35}$ and $222.5 \mu \mathrm{m}^{33}$ and values for internal fit ranged between $23 \mu \mathrm{m}^{35}$ and $406.5 \mu \mathrm{m} .{ }^{6}$ The $\%$ gap-free unit values for marginal fit ranged between $43 \%^{7}$ and $92 \%^{40}$ in dentin and $51 \%^{41}$ and $98.4 \%^{42}$ in enamel; values for internal fit ranged between $71 \%^{7}$ and $89 \%^{7}$ in dentin. Marginal fit was calculated between the restoration border and the preparation margin. When the specimens were sectioned, the marginal gap $(\mathrm{MG})^{47}$ was evaluated and 2 studies $^{34,37}$ also considered the absolute marginal discrepancy $(\mathrm{AMD})^{47}$; thus, some restorations can be either overextended or underextended. Overextension, which is the less favorable situation, may lead to plaque accumulation.

Nine articles evaluated marginal and internal fit with different restorative materials $24,28,33,34,38,41,42,44,46$ and five $\mathrm{e}^{24,33,34,42,46}$ showed that the performance of a CAD-CAM system 
relative to marginal/internal fit was influenced by the type of restorative material. For marginal fit, 3 studies $^{28,38,41}$ found no differences between a polymer-based and a glass-ceramic material, whereas 3 others showed significantly better adaptation for polymer-based materials, ${ }^{33,42}$ more specifically at the cervical margin. ${ }^{34}$ For internal fit, 3 studies ${ }^{28,34,46}$ demonstrated no significant difference between the 2 types of material, whereas 2 showed a significantly better adaptation for the polymer-based material ${ }^{33,42}$ but, for Bottino et al, ${ }^{33}$ only on the pulp wall. When 2 polymerbased blocks were compared, 1 study showed a significant difference for internal fit, ${ }^{46}$ and 1 showed a significant difference for both marginal and internal fit. ${ }^{24}$

Two studies reported that a more retentive preparation resulted in a higher overall internal gap $^{6}$ and a higher overall internal/marginal gap ${ }^{25}$ than a nonretentive preparation. Two studies evaluated marginal adaptation before and after cementation ${ }^{19,38}$ and concluded that resin cement with either self or total etch ${ }^{38}$ and with total etch only ${ }^{19}$ increased marginal discrepancies. In these 2 studies, the adhesive was not light polymerized before the restorations were seated.

Nine studies evaluated the quality of the marginal adaptation in micrometers ${ }^{17,19}$ or in $\%$ of continuous margin ${ }^{7,40-45}$ after aging. A significant reduction of continuous margin appeared after thermomechanical loading (TML) in 6 studies, ${ }^{7,40,41,43-45}$ whereas 2 did not show a statistically significant difference for marginal adaptation before/after TML ${ }^{17,19}$ and 1 found that TML can significantly improve marginal adaptation. ${ }^{42}$

One study ${ }^{20}$ compared 4 digital cameras (iTero, cara TRIOS, CEREC AC with Bluecam, and Lava COS) and concluded that differences among acquisition systems were statistically significant. iTero provided the best adaptation for marginal fit and CEREC AC with Bluecam provided the best adaptation for internal fit. Direct digitalization was preferred in 15 studies $^{6,7,20,21,24,25,28,34,36,39-42,44,46}$ and indirect digitalization was used in 8 studies. ${ }^{17,19,33,35,37,38,43,45}$ 
Only 1 study investigated adaptation whether the optical scan was made intraorally or extraorally from a gypsum die and found no statistically significant difference between the 2 techniques. ${ }^{21}$ One study demonstrated that a 5-axis milling machine provided a better occlusal marginal gap and better axial internal gap than a 3 -axis milling machine. ${ }^{37}$

The number of measuring points per specimen, when specified, ranged between $6^{34}$ and $600^{37}$ for marginal fit and $7^{35}$ and $320^{24}$ for internal fit. Some studies gave only a mean marginal/internal gap value, ${ }^{19,28,35}$ while others gave the mean corresponding values of each region, ${ }^{17,21,24,33,34,37-39}$ or at best, values of each reference point selected. ${ }^{6,25,36,46}$

Seven studies ${ }^{6,24,25,33,34,38,46}$ showed that the region measured was statistically significant in relation to marginal/internal adaptation. These studies used an analysis of variance (ANOVA) test followed by a Tukey test except 1 study which used a Dunnett T3 test. ${ }^{25}$ For marginal fit, only 1 study $^{38}$ gave values for the gingival, axial, and occlusal area in a direct measurement and showed that the larger gaps were obtained at the gingival margin. For internal fit, Rippe et $\mathrm{al}^{34}$ showed that the highest values of gap were obtained on the pulp wall, regardless of the type of materials. Furthermore, 4 studies in which values were recorded at each reference point showed that the larger gaps were obtained on the pulp and angle wall. ${ }^{6,24,25,46}$

Among the 23 studies selected, 3 specified the "luting space" value ${ }^{33,34,46}$ and 8 specified both "luting space" and "adhesive gap" values in the software. , $21,24,25,28,36-38$ The choice of the "luting space" value was set between 30 and $140 \mu \mathrm{m}$ and the "adhesive gap" value was set between 20 and $50 \mu \mathrm{m}$. All studies demonstrated that the values of adaptation recorded failed to reproduce the preestablished spacer parameters, with larger spacing showing throughout.

\section{DISCUSSION}


No consensus has been reached for a marginal discrepancy value that is clinically acceptable. ${ }^{27}$ Some authors have suggested it to be lower than $100 \mu \mathrm{m}^{21,37,48,49}$ but others felt that a gap lower than $120 \mu \mathrm{m}^{22,27,50-52}$ is a suitable threshold value. Most of the studies reported MG values within this range $(<120 \mu \mathrm{m})$. For internal adaptation, values between 70 and $120 \mu \mathrm{m}$ have been proposed. ${ }^{27,53}$ Studies reported that an internal gap of 50 to $100 \mu \mathrm{m}$ could result in the most favorable resin cement performance. ${ }^{54-56}$

To evaluate marginal/internal fit, a 2D analysis can be performed, but a limited number of measuring points and sections are possible. Therefore, results may not be representative of the whole fit of the restoration. ${ }^{35,57-60} 3 \mathrm{D}$ analysis as microcomputed tomography $(\mu-\mathrm{CT})^{25,54,56,61-65}$ and the triple-scan protocol ${ }^{20,59,66-69}$ can be used to evaluate marginal and internal fit. These 2 techniques provide multiple point measurements ${ }^{6,20,25,28,67,70}$ which cannot be achieved with a 2D-measurement. Hence, they can be considered to have high validity and reliability. ${ }^{20,67,68}$ A recent study showed that a triple-scan protocol produced a smaller marginal fit than the replica method with less data dispersion. ${ }^{68}$

The range of restorative CAD-CAM material can influence the marginal and internal adaptation of a restoration. ${ }^{61,63,71,72}$ This review showed that the performance of a CAD-CAM system relative to marginal/internal fit inlay/onlay restorations is influenced by the type of restorative material. Low hardness and modulus of elasticity have been shown to result in a greater amount of material being removed during grinding. ${ }^{73}$ Conversely, other studies have reported that less brittle materials have lower edge chipping, better machinability, ${ }^{74}$ and better adaptation. ${ }^{33,34}$ The type of milling bur and its behavior, according to the microstructure and the composition of the material should be further investigated. ${ }^{61,75}$ In addition, removal of the 
material induces vibrations and mechanical loads which can reflected on the surface dimensions and shape of the restoration. ${ }^{75}$

Inlay/onlays have a more complex geometry than crowns. This parameter is fundamental in explaining variations of adaptation in some areas and between a nonretentive and a retentive inlay/onlay preparation. ${ }^{6,19,25,70}$ The type of milling device could affect the results of adaptation, ${ }^{2,23,37,70,71,76}$ especially if the restoration has a complex shape, deep groove regions, and internal angles. When 2 different milling units were compared with the same scan system and CAD software, 4-axis milling units presented a lower accuracy of fit than 5-axis units, ${ }^{23,76}$ more particularly in occlusal marginal gap and axial internal gap. ${ }^{37}$ With a 5-axis unit, steep walls, small angles, and undercuts can be machined from different directions. ${ }^{2,70}$ The bur size and shape of the milling unit can influence the adaptation of a restoration. $2,4,25,61,67,70,77$ Overmilling of any surface details less than the diameter of the milling bur will result in a less accurate restoration, ${ }^{2,70}$ especially at the line angles of the preparation. ${ }^{56,66}$ A small diameter of $0.6 \mathrm{~mm}$ should be used when complex shapes are milled, ${ }^{77}$ as for inlay/onlay restorations.

The complex geometry of an inlay/onlay restoration can also influence the accuracy of the intraoral scan. ${ }^{25,61,70}$ Furthermore, the technology used by the scanner itself can influence the accuracy of the restoration, ${ }^{4,20,78-81}$ whereas few studies have shown any difference. ${ }^{5,68}$ Another influencing parameter is the luting space setting in the software. Almost $50 \%$ of the studies selected did not specify the virtual space parameter. It was shown that cement space settings had a statistically significant effect on the marginal fit of CAD-CAM restorations ${ }^{22,26,68}$ As the marginal fit improved, the cement space decreased. ${ }^{22}$ In addition, studies on crowns have also demonstrated that marginal and internal accuracy failed to reproduce the preestablished spacer parameters. ${ }^{82,83}$ Unlike direct digitalization, indirect digitalization needs a conventional 
impression with elastomeric materials in order to produce a gypsum cast. This methodology may thus lead to several potential sources of error because of dimensional deformations along the process chain. ${ }^{18,84-86}$ While Da Costa et $\mathrm{al}^{21}$ did not find a statistically significance difference for the marginal fit of onlays, 4 studies on crowns reported that direct digitalization demonstrated a better adaptation than indirect digitalization. ${ }^{18,81,86,87}$

This review had limitations. The high heterogeneity of the included studies prevented quantitative analyses of the data. Some parameters have been discussed based on few studies or even one, and although 33 studies were included, only one ${ }^{19}$ presented a low risk of bias according to the study quality assessment criteria used. Therefore, any general conclusions need to be drawn cautiously.

In vitro studies evaluating the adaptation of inlay/onlays are scarce compared with studies on crowns. Clarification is needed concerning adaptation of inlay/onlays according to the type of preparation design, the type of material, the choice of intrinsic parameters for the CAD process, the type and shape of milling burs, and the behavior of the material during milling. In vivo studies for inlay/onlays are even fewer ${ }^{88-92}$ and used the United States Public Health Service (USPHS) criteria to assess the quality of marginal adaptation. Moreover, the internal adaptation was not evaluated. In vivo, the replica technique can be used, and a 3D digital capture in 3 steps has recently been proposed to offer a more comprehensive assessment of restoration fit than a methodology in two dimensions. ${ }^{59}$

\section{CONCLUSIONS}

Based on this systematic review, the following conclusions were drawn:

1. Most of the studies reported a clinically acceptable range for marginal adaptation $(<120 \mu \mathrm{m})$ 
2. The performance of a CAD-CAM system relative to marginal/internal fit is influenced by the type of restorative material.

3. A nonretentive cavity preparation exhibited better adaptation than a retentive preparation.

4. Most studies showed that TML affected the quality of marginal adaptation. Cementation increased marginal discrepancies.

5. No statistically significant difference was found for the marginal fit of onlays between an intraoral and extraoral optical scan using a gypsum die.

6. Five-axis milling machines produced restorations with better fit than 3-axis milling machines.

7. The adaptation of a partial-coverage restoration depended on the digital scan technique used.

8. The region measured was statistically significant in relation to marginal/internal adaptation, with larger gaps at the gingival margin and on the pulp and angle wall.

9. For most studies, the values of adaptation recorded failed to reproduce the preestablished spacer parameters in the software, with larger spacing showing throughout. 


\section{REFERENCES}

1. van Noort R. The future of dental devices is digital. Dent Mater 2012;28:3-12.

2. Alghazzawi TF. Advancements in CAD/CAM technology: options for practical implementation. J Prosthodont Res 2016;602:72-84.

3. Fukazawa S, Odaira C, Kondo H. Investigation of accuracy and reproducibility of abutment position by intraoral scanners. J Prosthodont Res 2017;614:450-9.

4. De Paula Silveira AC, Chaves SB, Hilgert LA, Ribeiro AP. Marginal and internal fit of CADCAM-fabricated composite resin and ceramic crowns scanned by 2 intraoral cameras. J Prosthet Dent 2017;1173:386-92.

5. Abdel-Azim T, Rogers K, Elathamna E, Zandinejad A, Metz M, Morton D. Comparison of the marginal fit of lithium disilicate crowns fabricated with CAD/CAM technology by using conventional impressions and two intraoral digital scanners. J Prosthet Dent 2015;114:554-9. 6. Seo D, Yi Y, Roh B. The effect of preparation designs on the marginal and internal gaps in Cerec3 partial ceramic crowns. J Dent 2009;37:374-82.

7. Sandoval MJ, Rocca GT, Krejci I, Mandikos M, Dietschi D. In vitro evaluation of marginal and internal adaptation of class II CAD/CAM ceramic restorations with different resinous bases and interface treatments. Clin Oral Investig 2015;19:2167-77.

8. D'Arcangelo C, Zarow M, De Angelis F, Vadini M, Paolantonio M, Giannoni M, et al. Fiveyear retrospective clinical study of indirect composite restorations luted with a light-cured composite in posterior teeth. Clin Oral Investig 2014;18:615-24.

9. Zimmer S, Göhlich O, Rüttermann S, Lang H, Raab WH, Barthel CR. Long-term survival of Cerec restorations: a 10-year study. Oper Dent 2008;33:484-7. 
10. Li RW, Chow TW, Matinlinna JP. Ceramic dental biomaterials and CAD/CAM technology: state of the art. J Prosthodont Res 2014;58:208-16.

11. Denry I, Kelly JR. Emerging ceramic-based materials for dentistry. J Dent Res 2014;93:1235-42.

12. Ruse ND, Sadoun MJ. Resin-composite blocks for dental CAD/CAM applications. J Dent Res 2014;93:1232-34.

13. Mainjot AK, Dupont NM, OudkerkJC, Dewael TY, Sadoun MJ. From artisanal to CADCAM blocks: state of the art of indirect composites. J Dent Res 2016;95:487-95.

14. Awada A, Nathanson D. Mechanical properties of resin-ceramic CAD/CAM restorative material. J Prosthet Dent 2015;114:587-93.

15. Phan AC, Tang ML, Nguyen JF, Ruse ND, Sadoun MJ. High-temperature high-pressure polymerized urethane dimethacrylate-mechanical properties and monomer release. Dent Mater 2014;30:350-6.

16. Lawson NC, Bansal R, Burgess JO. Wear, strength, modulus and hardness of CAD/CAM restorative materials. Dent Mater 2016;32:275-83.

17. Stappert CF, Chitmongkolsuk S, Silva NR, Att W, Strub JR. Effect of mouth-motion fatigue and thermal cycling on the marginal accuracy of partial coverage restorations made of various dental materials. Dent Mater 2008;24:1248-57.

18. Ahrberg D, Lauer HC, Ahrberg M, Weigl P. Evaluation of fit and efficiency of CAD/CAM fabricated all-ceramic restorations based on direct and indirect digitalization: a double-blinded, randomized clinical trial. Clin Oral Investig 2016;20:291-300. 
19. Guess PC, Vagkopoulou T, Zhang Y, Wolkewitz M, Strub JR. Marginal and internal fit of heat pressed versus CAD/CAM fabricated all-ceramic onlays after exposure to thermomechanical fatigue. J Dent 2014;42:199-209.

20. Schaefer O, Decker M, Wittstock F, Kuepper H, Guentsch A. Impact of digital impression techniques on the adaptation of ceramic partial crowns in vitro. J Dent 2014;42:677-83. 21. Da Costa JB, Pelogia F, Hagedorn B, Ferracane JL. Evaluation of different methods of optical impression making on the marginal gap of onlays created with CEREC 3D. Oper Dent 2010;35:324-9.

22. Kale E, Seker E, Yilmaz B, Özcelik TB. Effect of cement space on the marginal fit of CADCAM-fabricated monolithic zirconia crowns. J Prosthet Dent 2016;116:890-5.

23. Zeltner M, Sailer I, Mühlemann S, Özcan M, Hämmerle CH, Benic GI. Randomized controlled within-subject evaluation of digital and conventional workflows for the fabrication of lithium disilicate single crowns. Part III: marginal and internal fit. J Prosthet Dent 2017;117:35462.

24. Park SH, Yoo YJ, Shin YJ, Cho BH, Baek SH. Marginal and internal fit of nano-composite CAD/CAM restorations. Restor Dent Endod 2016;41:37-43.

25. Kim JH, Cho BH, Lee JH, Kwon SJ, Yi YA, Shin Y, et al. Influence of preparation design on fit and ceramic thickness of CEREC 3 partial ceramic crowns after cementation. Acta Odontol Scand 2015;73:107-13.

26. Shim JS, Lee JS, Lee JY, Choi YJ, Shin SW, Ryu JJ. Effect of software version and parameter settings on the marginal and internal adaptation of crowns fabricated with the CAD/CAM system. J Appl Oral Sci 2015;23:515-22. 
27. Kim DY, Kim JH, Kim HY, Kim WC. Comparison and evaluation of marginal and internal gaps in cobalt-chromium alloy copings fabricated using subtractive and additive manufacturing. J Prosthodont Res 2018;6256-64.

28. Uzgur R, Ercan E, Uzgur Z, Çolak H, Yalçın M, Özcan M. Cement thickness of inlay restorations made of lithium disilicate, polymer-infiltrated ceramic and nano-ceramic CAD/CAM materials evaluated using 3D x-ray micro-computed tomography. J Prosthodont 2016;doi: 10.1111/jopr.12521. [Epub ahead of print]

29. Moher D, Shamseer L, Clarke M, Ghersi D, Liberati A, Petticrew M, et al. Preferred reporting items for systematic review and meta-analysis protocols (PRISMA-P) 2015 statement. Syst Rev 2015;4;doi: 10.1186/2046-4053-4-1.

30. Rosa WL, Piva E, Silva AF. Bond strength of universal adhesives: a systematic review and meta-analysis. J Dent 2015;43:765-76.

31. Sarkis-Onofre R, Skupien JA, Cenci MS, Moraes RR, Pereira-Cenci T. The role of resin cement on bond strength of glass-fiber posts luted into root canals: a systematic review and meta-analysis of in vitro studies. Oper Dent 2014;39:31-44.

32. Groten M, Axmann D, Pröbster L, Weber H. Determination of the minimum number of marginal gap measurements required for practical in vitro testing. J Prosthet Dent 2000;83:40-9. 33. Bottino MA, Campos F, Ramos NC, Rippe MP, Valandro LF, Melo RM. Inlays made from a hybrid material: adaptation and bond strength. Oper Dent 2015;40:83-91.

34. Rippe MP, Monaco C, Volpe L, Bottino MA, Scotti R, Valandro LF. Different methods for inlay production: effect on internal and marginal adaptation, adjustment time, and contact point. Oper Dent 2017;42:436-44. 
35. Keshvad A, Hooshmand T, Asefzadeh F, Khalilinejad F, Alihemmati M, Van Noort R. Marginal gap, internal fit, and fracture load of leucite-reinforced ceramic inlays fabricated by CEREC inLab and hot-pressed techniques. J Prosthodont 2011;20:535-40.

36. Reich S, Gozdowski S, Trentzsch L, Frankenberger R, Lohbauer U. Marginal fit of heatpressed vs. CAD/CAM processed all-ceramic onlays using a milling unit prototype. Oper Dent 2008;33:644-50.

37. Alajaji NK, Bardwell D, Finkelman M, Ali A. Micro-CT evaluation of ceramic inlays: comparison of the marginal and internal fit of five and three axis CAM systems with a heat press technique. J EsthetRestor Dent 2017;29:49-58.

38. Sener-Yamaner ID, Sertgöz A, Toz-Akalın T, Özcan M. Effect of material and fabrication technique on marginal fit and fracture resistance of adhesively luted inlays made of CAD/CAM ceramics and hybrid materials. J Adhes Sci Technol 2017;31:55-70.

39. Vanlioglu BA, Evren B, Yildiz C, Uludamar A, Ozkan YK. Internal and marginal adaptation of pressable and computer-aided design/computer-assisted manufacture onlay restorations. Inter J Prosthodont 2012;25:262-64.

40. Frankenberger R, Hehn J, Hajtó J, Krämer N, Naumann M, Koch A, et al. Effect of proximal box elevation with resin composite on marginal quality of ceramic inlays in vitro. Clin Oral Investig 2013;17:177-83.

41. Bortolotto T, Onisor I, Krejci I. Proximal direct composite restorations and chairside CAD/CAMinlays: marginal adaptation of a two-step self-etch adhesive with and without selective enamel conditioning. Clin Oral Investig 2007;11:35-43. 
42. Ilgenstein I, Zitzmann NU, Bühler J, Wegehaupt FJ, Attin T, Weiger R, et al. Influence of proximal box elevation on the marginal quality and fracture behavior of root-filled molars restored with CAD/CAM ceramic or composite onlays. Clin Oral Investig 2015;19:1021-28. 43. Zaruba M, Göhring TN, Wegehaupt FJ, Attin T. Influence of a proximal margin elevation technique on marginal adaptation of ceramic inlays. Acta Odontol Scand 2013;71:317-24. 44. Zaruba M, Kasper R, Kazama R, Wegehaupt FJ, Ender A, Attin T, et al. Marginal adaptation of ceramic and composite inlays in minimally invasive mod cavities. Clin Oral Investig 2014;18:579-87.

45. Rechenberg DK, Göhring TN, Attin T. Influence of different curing approaches on marginal adaptation of ceramic inlays. J Adhes Dent 2010;12:189-96.

46. Goujat A, Abouelleil H, Colon P, Jeannin C, Pradelle N, SeuxD, et al. Mechanical properties and internal fit of 4 CAD-CAM block materials. J Prosthet Dent 2018;119:384-9.

47. Holmes JR, Bayne SC, Holland GA, Sulik WD. Considerations in measurement of marginal fit. J Prosthet Dent 1989;62:405-8.

48. Kramer N, Lohbauer U, Frankenberger R. Adhesive luting of indirect restorations. Am J Dent 2000;13:60-76.

49. Roperto R, Assaf H, Soares-Porto T, Lang L, Teich S. Are different generations of CAD/CAM milling machines capable to produce restorations with similar quality? J Clin Exp Dent 2016;8:423-8.

50. McLean JW, von Fraunhofer JA. The estimation of cement film thickness by an in vivo technique. Br Dent J 1971;131:107-11.

51. Belser UC,MacEntee MI, Richter WA. Fit of three porcelain-fused-to-metal marginal designs in vivo: a scanning electron microscope study. J Prosthet Dent 1985;53:24-9. 
52. Sailer I, Feher A, Filser F, Gauckler LJ, Lüthy H, Hämmerle CH. Five-year clinical results of zirconia frameworks for posterior fixed partial dentures. Int J Prosthodont 2007;20:383-8.

53. Colpani JT, Borba M, Della Bona A. Evaluation of marginal and internal fit of ceramic crown copings. Dent Mater 2013;29:174-80.

54. Mously HA, Finkelman M, Zandparsa R, Hirayama H. Marginal and internal adaptation of ceramic crown restorations fabricated with $\mathrm{CAD} / \mathrm{CAM}$ technology and the heat-press technique. J Prosthet Dent 2014;112:249-56.

55. Lins L, Bemfica V, Queiroz C, Canabarro A. In vitro evaluation of the internal and marginal misfit of CAD/CAM zirconia copings. J Prosthet Dent 2015;113:205-11.

56. Alfaro DP, Ruse ND, Carvalho RM, Wyatt CC. Assessment of the internal fit of lithium disilicate crowns using micro-CT. J Prosthodont 2015;24:381-6.

57. Sakrana AA. In vitro evaluation of the marginal and internal discrepancies of different esthetic restorations. J Appl Oral Sci 2013;21:575-80.

58. Dauti R, Cvikl B, Franz A, Schwarze UY, Lilaj B, Rybaczek T, et al. Comparison ofmarginal fit of cemented zirconia copings manufactured after digital impression with lava C.O.S and conventional impression technique. BMC Oral Health 2016;16:129-37.

59. Park JM, Hämmerle CH, Benic GI. Digital technique for in vivo assessment of internal and marginal fit of fixed dental prostheses. J Prosthet Dent 2017;118:452-4.

60. OkaY, Sasaki J, Wakabayashi K, Nakano Y, Okamura SY, Nakamura T, et al. Fabrication of a radiopaque fit-testing material to evaluate the three-dimensional accuracy of dental prostheses. Dent Mater 2016;32:921-8.

61. Borba M, Cesar PF, Griggs JA, Della Bona A. Adaptation of all-ceramic fixed partial dentures. Dent Mater 2011;27:1119-26. 
62. Pimenta MA, Frasca LC, Lopes R, Rivaldo E. Evaluation of marginal and internal fit of ceramic and metallic crown copings using x-ray microtomography (micro-CT) technology.J Prosthet Dent 2015;114:223-8.

63. Demir N, Ozturk AN, Malkoc MA. Evaluation of the marginal fit of full ceramic crowns by the microcomputed tomography (micro-CT) technique. Eur J Dent 2014;8:437-44.

64. Neves FD, Prado CJ, Prudente MS, Carneiro TA, Zancopé K, Davi LR, et al. Microcomputed tomography evaluation of marginal fit of lithium disilicate crowns fabricated by using chairside CAD/CAM systems or the heat-pressing technique. J Prosthet Dent 2014;112:1134-40. 65. Carrera CA, Lan C, Escobar-Sanabria D, Li Y, Rudney J, Aparicio C. The use of micro-CT with image segmentation to quantify leakage in dental restorations. Dent Mater 2015;31:382-90. 66. Dahl BE, Rønold HJ, Dahl JE. Internal fit of single crowns produced by CAD-CAM and lostwax metal casting technique assessed by the triple-scan protocol. J Prosthet Dent 2017;117:4004.

67. Bae SY, Park JY, Jeong ID, Kim HY, Kim JH, Kim WC. Three-dimensional analysis of marginal and internal fit of copings fabricated with polyetherketoneketone (PEKK) and zirconia. J Prosthodont Res 2016;61:106-12.

68. Boitelle P, Tapie L, Mawussi B, Fromentin O. Evaluation of the marginal fit of CAD-CAM zirconia copings: comparison of 2D and 3D measurement methods. J Prosthet Dent 2018;119:7581.

69. Anadioti E, Aquilino SA, Gratton DG, Holloway JA, Denry I, Thomas GW, et al. 3D and 2D marginal fit of pressed and CAD/CAM lithium disilicate crowns made from digital and conventional impressions. J Prosthodont 2014;23:610-7. 
70. Kirsch C, Ender A, Attin T, Mehl A. Trueness of four different milling procedures used in dental CAD/CAM systems. Clin Oral Investig 2017;21:551-8.

71. Hamza TA, Ezzat HA, El-Hossary MM, Katamish HA, Shokry TE, Rosenstiel SF. Accuracy of ceramic restorations made with two CAD/CAM systems. J Prosthet Dent 2013;109:83-7. 72. Abdullah AO, Tsitrou EA, Pollington S. Comparative in vitro evaluation of CAD/CAM vs conventional provisional crowns. J Appl Oral Sci 2016;24:258-63.

73. Coldea A, Fischer J, Swain MV, Thiel N. Damage tolerance of indirect restorative materials (including PICN) after simulated bur adjustments. Dent Mater 2015;31:684-94.

74. Tsitrou EA, Northeast SE, van Noort R. Brittleness index of machinable dental materials and its relation to the marginal chipping factor. J Dent 2007;35:897-902.

75. Lebon N, Tapie L, Duret F, Attal JP. Understanding dental CAD/CAM for restorations dental milling machines from a mechanical engineering viewpoint. Part A: chairside milling machines. Int J Comput Dent 2016;19:45-62.

76. Bosch G, Ender A, Mehl A. A 3-dimensional accuracy analysis of chairside CAD/CAM milling processes. J Prosthet Dent 2014;112:1425-31.

77. Kim CM, Kim SR, Kim JH, Kim HY, Kim WC. Trueness of milled prostheses according to number of ball-end mill burs. J Prosthet Dent 2016;115:624-9.

78. Jung YR, Park JM, Chun YS, Lee KN, Kim M. Accuracy of four different digital intraoral scanners: effects of the presence of orthodontic brackets and wire. Inter J Comput Dent 2016;19:203-15.

79. Kim JH, Jeong JH, Lee JH, Cho HW. Fit of lithium disilicate crowns fabricated from conventional and digital impressions assessed with micro-CT. J Prosthet Dent 2016;1164:55155. 
80. Boeddinghaus M, Breloer ES, Rehmann P, Wöstmann B. Accuracy of single-tooth restorations based on intraoral digital and conventional impressions in patients. Clin Oral Investig 2015;19:2027-34.

81. Lim JH, Park JM, Kim M, Heo SJ, Myung JY. Comparison of digital intraoral scanner reproducibility and image trueness considering repetitive experience. J Prosthet Dent 2018;119:225-32.

82. Kocaağaoğlu H, Kılınç HI, Albayrak H. Effect of digital impressions and production protocols on the adaptation of zirconia copings. J Prosthet Dent 2017;117:102-8.

83. Boitelle P, Tapie L, Mawussi B, Fromentin O. 3D fitting accuracy evaluation of CAD/CAM copings - comparison with spacer design settings. Inter J Comput Dent 2016;19:27-43.

84. Güth JH, Keul C, Stimmelmayr M, Beuer F, Edelhoff D. Accuracy of digital models obtained by direct and indirect data capturing. Clin Oral Investig 2013;17:1201-08.

85. Vandeweghe S, Vervack V, Vanhove C, Dierens M, Jimbo R, De Bruyn H. Accuracy of optical dental digitizers: an in vitro study. Int J Periodontics \& Restorative Dent 2015;35:115-21. 86. Rudolph H, Salmen H, Moldan M, Kuhn K, Sichwardt V, Wöstmann B, et al. Accuracy of intraoral and extraoral digital data acquisition for dental restorations. J Appl Oral Sci 2016;24:85-94.

87. Vecsei B, Joós-Kovács G, Borbély J, Hermann P. Comparison of the accuracy of direct and indirect three-dimensional digitizing processes for CAD/CAM systems - An in vitro study. J Prosthodont Res 2017;61:177-84.

88. Federlin M, Hiller KA, Schmalz G. Effect of selective enamel etching on clinical performance of CAD/CAM partial ceramic crowns luted with a self-adhesive resin cement. Clin Oral Investig 2014;18:1975-84. 
89. Schenke F, Federlin M, Hiller KA, Moder D, Schmalz G. Controlled, prospective, randomized, clinical evaluation of partial ceramic crowns inserted with RelyXUnicem with or without selective enamel etching. Results after 2 years. Clin Oral Investig 2012;16:451-61. 90. Guess PC, Strub JR, Steinhart N, Wolkewitz M, Stappert CF. All-ceramic partial coverage restorations-midterm results of a 5-year prospective clinical splitmouth study. J Dent 2009;37:627-37.

91. Bernhart J, Schulze D, Wrbas KT. Evaluation of the clinical success of Cerec 3D inlays. Int J Comput Dent 2009;12:265-77.

92. Roggendorf MJ, Kunzi B, Ebert J, Roggendorf HC, Frankenberger R, Reich SM. Seven-year clinical performance of CEREC-2 all-ceramic CAD/CAM restorations placed within deeply destroyed teeth. Clin Oral Investig 2012;16:1413-24.

Corresponding author:

Dr Alexis Goujat

Laboratoire Multimatériaux et Interfaces (UMR CNRS 5615)

Faculté d'Odontologie

11, rue Guillaume Paradin

69372 Lyon

\section{FRANCE}

Email: alexis.goujat@etu.univ-lyon1.fr, alexis.goujat@orange.fr 
Acknowledgments

The authors would like to express their gratitude to L. Scalone for the English language verification. 


\section{TABLES}

Table 1. PubMed/MEDLINE search methodology

((fit[Text Word] OR gap[Text Word] OR internal[Text Word] OR marginal[Text Word] OR adaptation[Text Word] OR accuracy[Text Word] OR discrepancy[Text Word]) AND (resin[Text Word] OR composite[Text Word] OR ceramic[MeSH Terms]) AND (CAD [Text Word] OR computer-aided[Text Word]) AND (inlay*[MeSH Terms] OR onlay*[Text Word])) 
Supplemental Table 1.Quality assessment and risk of bias considering aspects reported in Material and Methods section

\begin{tabular}{|c|c|c|c|c|c|c|c|c|}
\hline Author, year of publication & $\begin{array}{c}\text { Teeth } \\
\text { Randomi- } \\
\text { zation }\end{array}$ & $\begin{array}{l}\text { Blinding } \\
\text { of the } \\
\text { Operator }\end{array}$ & $\begin{array}{c}\text { Number of } \\
\text { Measurement Point }(>50) \\
\text { per Specimen for Marginal } \\
\text { Fit }\end{array}$ & $\begin{array}{l}\text { Control } \\
\text { Group }\end{array}$ & $\begin{array}{c}\text { Statistical } \\
\text { Analysis } \\
\text { Carried out }\end{array}$ & $\begin{array}{c}\text { Gap Measurement } \\
\text { by a Single } \\
\text { Operator }\end{array}$ & $\begin{array}{c}\text { Luting } \\
\text { Space } \\
\text { Parameter } \\
(\mu \mathrm{m})\end{array}$ & $\begin{array}{c}\text { Risk of } \\
\text { Bias }\end{array}$ \\
\hline Bottino et al $(2015)^{33}$ & Yes & No & No & Yes & Yes & No & Yes & Medium \\
\hline Rippe et al $(2017)^{34}$ & Yes & No & No & Yes & Yes & No & Yes & Medium \\
\hline Parket al $(2016)^{24}$ & No & No & No & Yes & Yes & No & Yes & High \\
\hline Uzgur et al $(2016)^{28}$ & No & No & No & Yes & Yes & No & Yes & High \\
\hline Guess et al $(2014)^{19}$ & Yes & No & Yes & Yes & Yes & Yes & Yes & Low \\
\hline Alajaji et al $(2017)^{37}$ & No & No & Yes & Yes & Yes & Yes & Yes & Medium \\
\hline Da costa et al $(2010)^{21}$ & No & No & No & Yes & Yes & Yes & Yes & Medium \\
\hline Kim et al $(2015)^{25}$ & Yes & No & No & Yes & Yes & No & Yes & Medium \\
\hline Stappert et al $(2008)^{17}$ & No & No & Yes & Yes & Yes & No & No & High \\
\hline Seo et al $(2009)^{6}$ & Yes & No & No & Yes & Yes & No & Yes & Medium \\
\hline $\begin{array}{l}\text { Sener-yamaner } \\
\text { et } \mathrm{al}(2017)^{38}\end{array}$ & Yes & No & No & Yes & Yes & No & Yes & Medium \\
\hline Schaefer et al $(2014)^{20}$ & No & No & No & Yes & Yes & No & No & High \\
\hline Goujat et al (2017) & No & No & No & Yes & Yes & No & Yes & High \\
\hline
\end{tabular}


Supplemental Table 1. (Continued)

\begin{tabular}{|c|c|c|c|c|c|c|c|c|}
\hline Author, year of publication & $\begin{array}{c}\text { Teeth } \\
\text { Randomi- } \\
\text { zation }\end{array}$ & $\begin{array}{l}\text { Blinding } \\
\text { of the } \\
\text { Operator }\end{array}$ & $\begin{array}{c}\text { Number of } \\
\text { Measurement Point }(>50) \\
\text { per Specimen for Marginal } \\
\text { Fit }\end{array}$ & $\begin{array}{l}\text { Control } \\
\text { Group }\end{array}$ & $\begin{array}{c}\text { Statistical } \\
\text { Analysis } \\
\text { Carried out }\end{array}$ & $\begin{array}{l}\text { Gap Measurement } \\
\text { by a Single } \\
\text { Operator }\end{array}$ & $\begin{array}{c}\text { Luting } \\
\text { Space } \\
\text { Parameter } \\
(\mu \mathrm{m})\end{array}$ & $\begin{array}{c}\text { Risk of } \\
\text { Bias }\end{array}$ \\
\hline Keshvad et al $(2011)^{35}$ & Yes & No & No & Yes & Yes & Yes & No & Medium \\
\hline Reich et al $(2008)^{36}$ & Yes & No & No & Yes & Yes & Yes & Yes & Medium \\
\hline Vanlioglu et al $(2012)^{39}$ & No & No & No & Yes & Yes & No & No & High \\
\hline $\begin{array}{l}\text { Frankenberger et al } \\
(2013)^{40}\end{array}$ & No & Yes & NA & Yes & Yes & Yes & No & Medium \\
\hline Sandoval et al $(2015)^{7}$ & Yes & Yes & NA & Yes & Yes & Yes & No & Medium \\
\hline Bortolotto et al $(2007)^{41}$ & Yes & No & NA & Yes & Yes & No & No & High \\
\hline Ilgenstein et al $(2015)^{42}$ & Yes & No & NA & Yes & Yes & Yes & No & Medium \\
\hline Zaruba et al $(2013)^{43}$ & Yes & No & NA & Yes & Yes & Yes & No & Medium \\
\hline Zaruba et al $(2014)^{44}$ & Yes & Yes & NA & Yes & Yes & Yes & No & Medium \\
\hline Rechenberg et al $(2010)^{45}$ & Yes & Yes & NA & Yes & Yes & Yes & No & Medium \\
\hline
\end{tabular}


Supplemental Table 2. Data collected from studies evaluating marginal/internal fit $(\mu \mathrm{m})$

\begin{tabular}{|c|c|c|c|c|c|c|c|c|}
\hline $\begin{array}{l}\text { Author, } \\
\text { Year of } \\
\text { Publication }\end{array}$ & $\begin{array}{l}\text { CAD-CAM } \\
\text { System }\end{array}$ & $\begin{array}{c}\text { Space } \\
\text { Parameters } \\
\mu \mathrm{m}\end{array}$ & $\begin{array}{l}\text { Software } \\
\text { Version }\end{array}$ & Type of Block & $\begin{array}{l}\text { Restoration/ } \\
\text { Sample size/ } \\
\text { Aging }\end{array}$ & $\begin{array}{c}\text { Number of } \\
\text { Measuring } \\
\text { Points per Specimen }\end{array}$ & $\begin{array}{l}\text { Mean Internal Fit } \\
\mu \mathrm{m} \\
( \pm \mathrm{SD}) \text { ou }(95 \% \mathrm{CI})\end{array}$ & $\begin{array}{l}\text { Mean Marginal Fit } \\
\mu \mathrm{m} \\
( \pm \mathrm{SD}) \text { ou }(95 \% \mathrm{CI})\end{array}$ \\
\hline $\begin{array}{l}\text { Bottino et al } \\
(2015)^{33}\end{array}$ & $\begin{array}{l}\text { CEREC } \\
\text { MC XL }\end{array}$ & Luting space 80 & NS & $\begin{array}{l}\text { Enamic (EN) } \\
\text { Vita Mark II (VM) }\end{array}$ & $\begin{array}{l}\text { Inlay/ } \\
20(10 x 2)\end{array}$ & $\begin{array}{l}16 \text { (marginal) } \\
\text { NS(internal) }\end{array}$ & $\begin{array}{l}\text { (EN) } 124( \pm 18) \text { to } 130.1( \pm 26) \\
(\mathrm{VM}) 210.6( \pm 75) \text { to } 137.8( \pm 40)\end{array}$ & $\begin{array}{l}\text { (EN) } 163.1( \pm 53) \text { to } 159.6( \pm 36) \\
\text { (VM) } 222.5( \pm 46) \text { to } 208.9( \pm 54)\end{array}$ \\
\hline $\begin{array}{l}\text { Rippe et al } \\
(2017)^{34}\end{array}$ & $\begin{array}{l}\text { Lava COS } \\
\text { CEREC }\end{array}$ & $\begin{array}{l}\text { Luting space } 45 \\
\text { Luting space } 40\end{array}$ & NS & $\begin{array}{l}\text { e.max CAD (EM) } \\
\text { Lava Ultimate (LU) }\end{array}$ & $\begin{array}{l}\text { Inlay/ } \\
30(10 \times 3)\end{array}$ & $\begin{array}{l}\text { 6(marginal) } \\
\text { 19(internal) }\end{array}$ & $\begin{array}{l}\text { (EM) } 66.7( \pm 19.9) \text { to } 207.2 \\
( \pm 61.3) \\
(\mathrm{LU}) 76.7( \pm 24.6) \text { to } 233.8 \\
( \pm 80.5)\end{array}$ & $\begin{array}{l}\text { (EM) } 171.8( \pm 56.6) \text { to } 177.8 \\
( \pm 68.9) \\
(\mathrm{LU}) 105.9( \pm 40.3) \text { to } 145.3 \\
( \pm 106.5)\end{array}$ \\
\hline $\begin{array}{l}\text { Park et al } \\
(2016)^{24}\end{array}$ & $\begin{array}{l}\text { CEREC } \\
\text { Bluecam }\end{array}$ & $\begin{array}{l}\text { Luting space } 140 \\
\text { Adhesive gap } 20\end{array}$ & 4.0 & $\begin{array}{l}\text { Lava Ultimate (LU) } \\
\text { Exp Resin Comp. (ERC) }\end{array}$ & $\begin{array}{l}\text { Onlay/ } \\
10\end{array}$ & $\begin{array}{l}\text { NS(marginal) } \\
320 \text { (internal) }\end{array}$ & $\begin{array}{l}\text { (LU) } 90.76( \pm 8.35) \text { to } 186.54 \\
( \pm 10.52) \\
(\text { ERC) } 118.86( \pm 11.25) \text { to } 222.50 \\
( \pm 10.38)\end{array}$ & $\begin{array}{l}\text { (LU) } 48.72( \pm 4.07) \\
\text { (ERC) } 55.27( \pm 6.40)\end{array}$ \\
\hline $\begin{array}{l}\text { Keshvad et al } \\
(2011)^{35}\end{array}$ & $\begin{array}{l}\text { CEREC } \\
\text { inLab }\end{array}$ & NS & NS & ProCAD & $\begin{array}{l}\text { Inlay/ } \\
25 \text { (marginal) } \\
10 \text { (internal) } \\
\end{array}$ & $\begin{array}{l}\text { 12(marginal) } \\
7 \text { (internal) }\end{array}$ & $23( \pm 9)$ & $36( \pm 11)$ \\
\hline $\begin{array}{l}\text { Guess et al } \\
(2014)^{19}\end{array}$ & $\begin{array}{l}\text { CEREC } \\
\text { InLab 3D }\end{array}$ & NS & 3.01 & e.max CAD & $\begin{array}{l}\text { Onlay/ } \\
8-24(\text { marginal) } \\
16 \text { (internal)/TMF }\end{array}$ & $\begin{array}{l}\text { 400-500(marginal) } \\
66 \text { (internal) }\end{array}$ & $103.37(96.66-110.08)$ & $\begin{array}{l}50.09(47.18-52.99) \\
\text { to } \\
54.05(52.26-55.84)\end{array}$ \\
\hline $\begin{array}{l}\text { Reich et al } \\
(2008)^{36}\end{array}$ & $\begin{array}{l}\text { CEREC 3D } \\
\text { MC XL } \\
\end{array}$ & $\begin{array}{l}\text { Luting space } 40 \\
\text { Adhesive gap } 20\end{array}$ & 3.0 & Cerec blocs & $\begin{array}{l}\text { Onlays/ } \\
16 \\
\end{array}$ & 385 & - & $\begin{array}{l}70( \pm 32)(60-79) \\
\text { to } 94( \pm 30)(78-110)\end{array}$ \\
\hline $\begin{array}{l}\text { Uzguret al } \\
(2016)^{28}\end{array}$ & 3 shape & $\begin{array}{l}\text { Luting space } 40 \\
\text { Adhesive gap } 20\end{array}$ & NS & $\begin{array}{l}\text { e.max CAD (EM) } \\
\text { Enamic (EN) } \\
\text { Cerasmart (CER) }\end{array}$ & $\begin{array}{l}\text { Inlay/ } \\
30(10 \times 3)\end{array}$ & NS & $\begin{array}{l}\text { (EM) } 60.58( \pm 9.22) \\
(\mathrm{EN}) 77.53( \pm 12.13) \\
(\mathrm{CER}) 54.85( \pm 6.94)\end{array}$ & $\begin{array}{l}\text { (EM) } 67.54( \pm 10.16) \\
(\mathrm{EN}) 84.09( \pm 3.94) \\
(\mathrm{CER}) 95.18( \pm 10.58) \\
\end{array}$ \\
\hline $\begin{array}{l}\text { Alajajiet al } \\
(2017)^{37}\end{array}$ & E4D & $\begin{array}{l}\text { Luting space } 100 \\
\text { Adhesive gap } 25\end{array}$ & NS & e.max CAD & $\begin{array}{l}\text { Inlay/ } \\
30\end{array}$ & $\begin{array}{c}600(\text { marginal }) \\
240 \text { (internal) }\end{array}$ & $\begin{array}{l}104.98( \pm 14.05) \text { to } 216.81 \\
( \pm 34.34)\end{array}$ & $\begin{array}{l}51.08( \pm 12.46) \text { to } 79.93( \pm 19.41) \\
{[\text { AMD 58.75 ( } \pm 9.95) \text { to } 99.83} \\
( \pm 16.68)]\end{array}$ \\
\hline $\begin{array}{l}\text { Da costa et al } \\
(2010)^{21}\end{array}$ & CEREC 3D & $\begin{array}{ll}\text { Luting space } 50 \\
\text { Adhesive gap } 50 \\
\end{array}$ & NS & Vita Mark II & $\begin{array}{l}\text { Onlay/ } \\
12 \\
\end{array}$ & 12 & - & $91( \pm 19.71)$ to $147.5( \pm 25.88)$ \\
\hline $\begin{array}{l}\text { Kim et al } \\
(2015)^{25}\end{array}$ & $\begin{array}{l}\text { CEREC 3 } \\
\text { Bluecam } \\
\text { Cerec MC }\end{array}$ & $\begin{array}{ll}\text { Luting space } 30 \\
\text { Adhesive gap } 20\end{array}$ & 3.85 & Empress CAD & $\begin{array}{l}\text { Retentive(R)-None } \\
\text { retentive(NR) onlay } \\
/ 16(8 \times 2)\end{array}$ & $\begin{array}{c}\text { (R) 16(marginal) } \\
76 \text { (internal) } \\
\text { (NR) 16(marginal) } \\
66 \text { (internal) } \\
\end{array}$ & $\begin{array}{l}\text { (R)160 }( \pm 37.8) \text { to } 306.8( \pm 52.7) \\
(\mathrm{NR}) 135( \pm 80.5) \text { to } 235.9 \\
( \pm 53.2)\end{array}$ & $\begin{array}{l}\text { (R) } 82.6( \pm 29.9) \text { to } 142.6( \pm 54.2) \\
\text { (NR) } 81( \pm 39.7) \text { to } 93.3( \pm 37.1)\end{array}$ \\
\hline
\end{tabular}

NS: Not Specified, TML: Thermomechanical Loading, TMF: Thermomechanical Fatigue, AMD: Absolute Marginal Discrepancy 
Supplemental Table 2. (Continued)

\begin{tabular}{|c|c|c|c|c|c|c|c|c|}
\hline $\begin{array}{l}\text { Author, Year of } \\
\text { Publication }\end{array}$ & $\begin{array}{l}\text { CAD-CAM } \\
\text { System }\end{array}$ & $\begin{array}{c}\text { Space } \\
\text { Parameters } \\
\mu \mathrm{m}\end{array}$ & $\begin{array}{l}\text { Software } \\
\text { Version }\end{array}$ & Type of Block & $\begin{array}{l}\text { Restoration/ } \\
\text { Sample size/ } \\
\text { Aging }\end{array}$ & $\begin{array}{l}\text { Number of } \\
\text { Measuring } \\
\text { Points per } \\
\text { Specimen }\end{array}$ & $\begin{array}{c}\text { Mean Internal Fit } \\
\mu \mathrm{m} \\
( \pm \mathrm{SD}) \text { ou } \\
(95 \% \mathrm{CI}) \\
\end{array}$ & $\begin{array}{c}\text { Mean Marginal Fit } \\
\mu \mathrm{m} \\
( \pm \mathrm{SD}) \text { ou }(95 \% \mathrm{CI})\end{array}$ \\
\hline $\begin{array}{l}\text { Stappert et al } \\
(2008)^{17}\end{array}$ & CEREC 3 & NS & NS & $\overline{\text { proCAD }}$ & $\begin{array}{l}\text { Onlay/16/ } \\
\text { TML }\end{array}$ & 450 & - & $\begin{array}{l}\text { Luted 27.5 } \\
( \pm 36.2) \text { to } \\
68.9( \pm 23.03) \\
\text { Aged 51.4 } \\
( \pm 11.34) \text { to } \\
94( \pm 37.7) \\
\end{array}$ \\
\hline $\begin{array}{l}\text { Seoet al } \\
(2009)^{6}\end{array}$ & CEREC 3D & $\begin{array}{ll}\text { Luting space } & 30 \\
\text { Adhesive gap } & 30\end{array}$ & 3.05 & proCAD & $\begin{array}{l}\text { Onlay/ } \\
60(20 \times 3)\end{array}$ & $\begin{array}{l}20 \text { (marginal) } \\
61 \text { to } 105 \text { (internal) }\end{array}$ & $\begin{array}{l}50.5( \pm 46.5) \text { to } \\
406.5( \pm 176.1)\end{array}$ & $\begin{array}{l}35.4( \pm 32.2) \text { to } \\
128.4( \pm 69.5)\end{array}$ \\
\hline $\begin{array}{l}\text { Sener-yamaner } \\
\text { et al }(2017)^{38}\end{array}$ & $\begin{array}{l}\text { CEREC 3D } \\
\text { MC XL }\end{array}$ & $\begin{array}{ll}\text { Luting space } & 30 \\
\text { Adhesive gap } & 30\end{array}$ & 4.2 .1 & $\begin{array}{l}\text { e.max CAD (EM) } \\
\text { Lava Ultimate } \\
\text { (LU) }\end{array}$ & $\begin{array}{l}\text { Inlay/ } \\
40(20 \times 2)\end{array}$ & 18 & - & $\begin{array}{l}\text { (EM) 56.75 } \\
( \pm 17.69) \text { to } 107.53 \\
( \pm 17.58) \\
\text { (LU) 60.74 } \\
( \pm 16.02) \text { to } 109.45 \\
( \pm 14.03)\end{array}$ \\
\hline $\begin{array}{l}\text { Schaefer et al } \\
(2014)^{20}\end{array}$ & $\begin{array}{c}\text { iTero(ITE) } \\
\text { TRIOS(TRI) } \\
\text { CEREC(CBC) } \\
\text { Lava(COS) }\end{array}$ & NS & NS & e.max CAD & $\begin{array}{l}\text { Onlay/ } \\
20(4 \times 5)\end{array}$ & NS & $\begin{array}{l}\text { (ITE) } 92( \pm 9)(\mathrm{CI} \\
81-104) \\
(\mathrm{TRI}) 106( \pm 7) \\
\text { (CI } 117-139) \\
\text { (CBC) } 84( \pm 16) \\
\text { (CI } 63-104 \\
\text { (COS) } 92( \pm 10) \\
\text { (CI } 80-105)\end{array}$ & $\begin{array}{l}(\text { ITE) } 90( \pm 14)(71 \\
-108) \\
(\mathrm{TRI}) 128( \pm 9) \\
(117-139) \\
(\mathrm{CBC}) 146( \pm 17) \\
(125-167) \\
(\mathrm{COS}) 109( \pm 11) \\
(96-123)\end{array}$ \\
\hline $\begin{array}{l}\text { Vanlioglu et al } \\
(2012)^{39}\end{array}$ & NS & NS & NS & e.max CAD & $\begin{array}{l}\text { Onlay/ } \\
20\end{array}$ & 40 & $\begin{array}{l}132.77( \pm 31.32) \\
\text { to } 196.49 \\
( \pm 31.32)\end{array}$ & $\begin{array}{l}112.14( \pm 15.64) \text { to } \\
119.65( \pm 38.16)\end{array}$ \\
\hline $\begin{array}{l}\text { Goujat et al } \\
(2017)^{46}\end{array}$ & $\begin{array}{l}\text { CEREC 3D } \\
\text { MC XL }\end{array}$ & Luting space 120 & 4.3 & $\begin{array}{l}\text { e.max CAD (EM) } \\
\text { Enamic (EN) } \\
\text { Lava Ultimate } \\
\text { (LU) } \\
\text { Cerasmart (CER) }\end{array}$ & $\begin{array}{l}\text { Inlay/ } \\
60(15 \times 4)\end{array}$ & 9 & $\begin{array}{l}\text { (EM) } 122( \pm 35) \text { to } \\
217( \pm 46) \\
(\mathrm{EN}) 119 \pm(55) \text { to } \\
234( \pm 51) \\
(\mathrm{LU}) 158 \pm(79) \text { to } \\
231 \pm(51) \\
(\mathrm{CER}) 127 \pm(39) \\
\text { to } \\
205 \pm(40)\end{array}$ & - \\
\hline
\end{tabular}

NS: Not Specified, TML: Thermomechanical Loading, TMF: Thermomechanical Fatigue, AMD: Absolute Marginal Discrepancy 
Supplemental Table 3. Data collected from studies evaluating marginal/internal fit (\%gap free)

\begin{tabular}{|c|c|c|c|c|c|c|c|c|}
\hline $\begin{array}{l}\text { Author, Year of } \\
\text { Publication }\end{array}$ & $\begin{array}{l}\text { CAD-CAM } \\
\text { System }\end{array}$ & $\begin{array}{c}\text { Space } \\
\text { Parameters } \\
\mu \mathrm{m}\end{array}$ & $\begin{array}{l}\text { Software } \\
\text { Version }\end{array}$ & Type of Block & $\begin{array}{l}\text { Restoration/ } \\
\text { Sample size/ } \\
\text { Aging }\end{array}$ & $\begin{array}{c}\text { Number of } \\
\text { Measuring Points } \\
\text { per Specimen }\end{array}$ & $\begin{array}{c}\text { Mean Internal Fit } \\
\text { (marginal quality }-\% \text { gap free }) \% \\
( \pm \% \text { SD) or }(95 \% \mathrm{CI}) \\
\text { After Aging } \\
\end{array}$ & $\begin{array}{c}\text { Mean Marginal Adaptation } \\
\text { (marginal quality - \% gap } \\
\text { free) } \% \text { ( } \pm \% \text { SD) or }(95 \% \mathrm{CI}) \\
\text { After Aging } \\
\end{array}$ \\
\hline $\begin{array}{l}\text { Frankenberger et al } \\
(2013)^{40}\end{array}$ & NS & NS & NS & Empress CAD & $\begin{array}{l}\text { Inlay/48(8x6)/ } \\
\text { TML }\end{array}$ & - & - & $\begin{array}{l}\text { Dentin } \\
92( \pm 7)\end{array}$ \\
\hline $\begin{array}{l}\text { Sandoval et al } \\
(2015)^{7}\end{array}$ & CEREC 3D & NS & 3.10 & Empress CAD & $\begin{array}{l}\text { Inlay/32(8x4)/ } \\
\text { ML }\end{array}$ & - & $\begin{array}{c}\text { Dentin } \\
71( \pm 29) \text { to } 89( \pm 14)\end{array}$ & $\begin{array}{c}\text { Dentin } \\
43( \pm 32) \text { to } 63( \pm 15) \\
\text { Enamel } \\
62( \pm 6) \text { to } 63( \pm 15)\end{array}$ \\
\hline $\begin{array}{l}\text { Bortolotto et al } \\
(2007)^{41}\end{array}$ & CEREC 3D & NS & 2.60 & $\begin{array}{l}\text { Vita Mark II (VM) } \\
\text { Paradigm (P) }\end{array}$ & $\begin{array}{l}\text { Inlay/24(12x2)/ } \\
\text { TML }\end{array}$ & - & - & $\begin{array}{c}\text { Enamel } \\
\text { (VM) } 51( \pm 10.5) \text { to } 66.2( \pm 10.3) \\
(\mathrm{P}) 58.8( \pm 14.6) \text { to } 80.2( \pm 14.3)\end{array}$ \\
\hline $\begin{array}{l}\text { Ilgenstein et al } \\
(2015)^{42}\end{array}$ & $\begin{array}{l}\text { CEREC } \\
\text { Bluecam }\end{array}$ & NS & 4.03 & $\begin{array}{l}\text { Vita Mark II (VM) } \\
\text { Lava Ultimate (LU) }\end{array}$ & $\begin{array}{l}\text { Onlay/48(24x2)/ } \\
\text { TML }\end{array}$ & - & - & $\begin{array}{c}\text { Enamel } \\
\text { (VM) } 69.8(61.4 \text { - 78.1) } \\
\text { (LU) } 98.4(97.2 \text { - 99.6) }\end{array}$ \\
\hline $\begin{array}{l}\text { Zaruba et al } \\
(2013)^{43}\end{array}$ & CEREC 3D & NS & 3.60 & Vita Mark II & $\begin{array}{l}\text { Inlay/40(10x4)/ } \\
\text { TML }\end{array}$ & - & - & $\begin{array}{c}\text { Dentin } \\
75.6( \pm 6.6) \\
\text { Enamel } \\
87.8( \pm 4.3) \text { to } 90( \pm 6.4)\end{array}$ \\
\hline $\begin{array}{l}\text { Zaruba et al } \\
(2014)^{44}\end{array}$ & CEREC & NS & 3.80 & $\begin{array}{c}\text { Empress CAD }(\mathrm{EM}) \\
\text { Paradigm }(\mathrm{P})\end{array}$ & $\begin{array}{l}\text { Inlay/40(10x4)/ } \\
\text { TML }\end{array}$ & - & - & $\begin{array}{c}\text { Dentin } \\
\text { (P) } 79.8( \pm 27)(\mathrm{EM}) 79.9( \pm 16.1) \\
\text { Enamel } \\
\text { (P) } 73.8( \pm 17.2)(\mathrm{EM}) 85.6( \pm 8.8)\end{array}$ \\
\hline $\begin{array}{l}\text { Rechenberg et al } \\
(2010)^{45}\end{array}$ & CEREC & NS & 2.70 & Vita Mark II & $\begin{array}{l}\text { Inlay/40(6x8)/ } \\
\text { TML }\end{array}$ & - & - & $\begin{array}{c}\text { Dentin } \\
57.0( \pm 17) \text { to } 89.9( \pm 4.9) \\
\text { Enamel } \\
54.7( \pm 11.9) \text { to } 72.5( \pm 6.1)\end{array}$ \\
\hline
\end{tabular}

NS: Not Specified, TML: ThermoMechanical Loading, ML: Mechanical Loading 


\section{FIGURES}

Figure 1. PRISMA flow diagram of literature search and selection process.

Figure 2. Type of methodology used for evaluation of marginal/internal fit CAD-CAM inlay/onlays. 
Figure 1. PRISMA flow diagram of literature search and selection process.

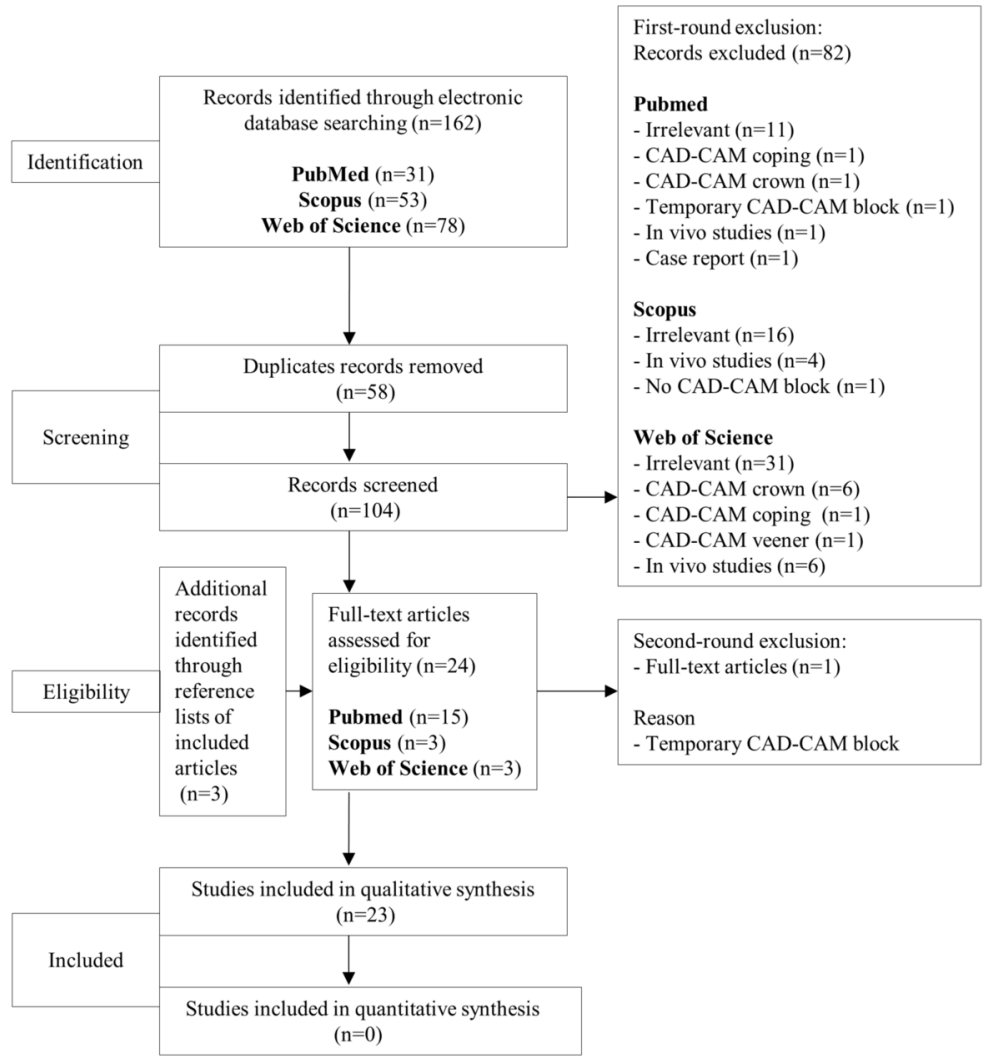




\section{MARGINAL FIT (22 studies)}

\section{DIRECT MEASURE (17 studies)}

\section{Cementation \\ No section}

Keshvad et al ${ }^{35}(\mu \mathrm{m})$ (dye penetration) $\mathrm{mO}[\mathrm{RC}+\mathrm{TE}]$

Stappert et al $^{17}(\mu \mathrm{m}) \mathrm{mO}[\mathrm{RC}+\mathrm{TE}]$

Park et $\mathrm{al}^{24}(\mu \mathrm{m}) \mathrm{mO}[\mathrm{RC}+\mathrm{SE}]$

Sandoval et $\mathrm{al}^{7}$ (\%gap free) SEM [RC+TE]

Bortolotto et $\mathrm{al}^{41}$ (\%gap free) SEM [RC+SE +/- EE]

Ilgenstein et $\mathrm{al}^{42}$ (\%gap free) SEM [RC+TE]

Zaruba et $\mathrm{al}^{43}$ (\%gap free) SEM [RC+SE]

Zaruba et $\mathrm{l}^{44}$ (\%gap free) SEM [RC+TE]

Rechenberg et al ${ }^{45}$ (\%gap free) SEM [RC+TE]

Frankenberger et al ${ }^{40}$ (\%gap frec) SEM [RC+TE]

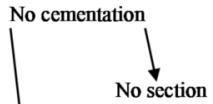

Bottino et al ${ }^{33}(\mu \mathrm{m}) \mathrm{mO}$

Reich et al ${ }^{36}(\mu \mathrm{m}) \mathrm{mO}$

Da costa et $\mathrm{al}^{21}(\mu \mathrm{m}) \mathrm{mO}$
Before/After cementation

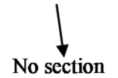

Guess et al ${ }^{19}(\mu \mathrm{m})$

$\mathrm{mO}[\mathrm{RC}+\mathrm{TE}]$

Sener-Yamaner et $\mathrm{al}^{38}(\mu \mathrm{m})$

$\mathrm{mO}[\mathrm{RC}+\mathrm{TE} / \mathrm{SE}]$
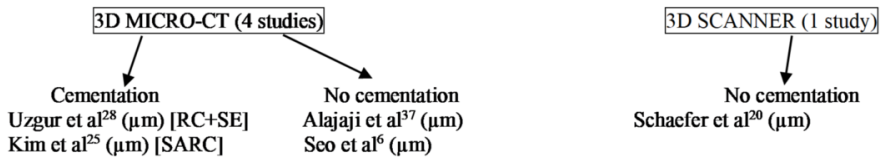

Schaefer et $\mathbf{a l}^{20}(\mu \mathrm{m})$

Vanlioglu et $\mathrm{al}^{39}(\mu \mathrm{m}) \mathrm{mO}$ (Silicone replica technique)

Rippe et al ${ }^{34}(\mu \mathrm{m}) \mathrm{mO}$ (Silicone replica technique)

\section{INTERNAL FIT (13 studies)}

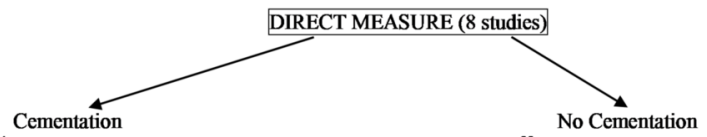

Park et $\mathrm{al}^{24}(\mu \mathrm{m}) \mathrm{mO}[\mathrm{RC}+\mathrm{SE}]$

Keshvad et $\mathrm{al}^{35}(\mu \mathrm{m})$ (dye penetration) $\mathrm{mO}$ [RC+TE]

Guess et al ${ }^{19}(\mu \mathrm{m}) \mathrm{mO}$ [RC+TE]

Sandoval et $\mathrm{al}^{7}(\mu \mathrm{m})$ SEM $[\mathrm{RC}+\mathrm{TE}]$
Bottino et $\mathrm{al}^{33}(\mu \mathrm{m}) \mathrm{mO}$ (Silicone replica technique) Rippe et al ${ }^{34}(\mu \mathrm{m}) \mathrm{mO}$ (Silicone replica technique) Vanlioglu et $\mathrm{al}^{39}(\mu \mathrm{m}) \mathrm{mO}$ (Silicone replica technique) Goujat et al ${ }^{46}(\mu \mathrm{m}) \mathrm{mO}$ (Silicone replica technique)

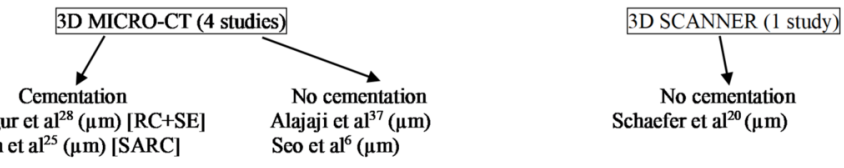

